Athens Journal of Business \& Economics -

Volume 8, Issue 2, April 2022 -Pages 177-192

\title{
Greece in the Eurozone: An Evaluation of the First Two Decades
}

\author{
By Gregory T. Papanikos"
}

\begin{abstract}
On the $31^{\text {st }}$ of December 2021, the euro celebrated its two decades in circulation. Initially, twelve countries adopted the euro as their new national currency, Greece being one of them. Starting in 2020, euro is the official currency of nineteen European Union countries. This paper aims to examine three issues. Firstly, the paper investigates Greek people's perception about the euro, using data from the recent issue of the Eurobarometer (December 2021). Secondly, the economic performance of Greece is briefly examined by comparing the Greek Gross Domestic Product (GDP) two decades before and two decades after the introduction of euro. Finally, the Greek participation to the eurozone has been a controversial, political issue. The political developments in Greece during the first two decades of the euro are also studied, emphasizing the dramatic political events after the double elections of 2012. The period of the two decades ends with the detrimental impact of COVID-19. This issue is also mentioned by reviewing some recent publications.
\end{abstract}

Keywords: Eurozone, Greece, GDP, per capita GDP, Eurobarometer, euro, elections, politics

\section{Introduction}

This paper evaluates the first two decades of Greece's membership to the eurozone. The euro circulated with coins and banknotes on 1 January 2002. Many hoped for the best and few feared for the worst. Based on my published work on this issue, ${ }^{1}$ which was the result of being both an academic economist and an active policymaker, an effort is made here to gauge whether the Greek economy is worse off, relative to what would have been the case if Greece had stayed outside the euro, and instead keeping its national currency of drachmae. Of course, it is impossible to simulate 20 years of economic performance with the drachmae and compare it with the actual economic performance within the eurozone. Thus, the analysis is rather speculative.

The costs and benefits of the Greek decision to be a member of the eurozone was investigated by Papadopoulos and Papanikos (1997) after a request by the Greek Government. The part of this report which dealt with the costs of Greece's euro expected at the time are included in an appendix in Papanikos (2014a). That was an ex-ante evaluation of the euro effect on the Greek economy. This study attempts an ex-post evaluation, but it is not an easy task because during this period

\footnotetext{
*President, Athens Institute for Education and Research, Greece; Honorary Professor of Economics, University of Stirling, UK; and Professor, MLC Ljubljana, Slovenia.

${ }^{1}$ The cited publications include the relevant references, which readers can access them if they are interested.
} 
of twenty years, the Greek economy was influenced by three events, two of which were noneconomic.

The first noneconomic event was the Olympic Games of 2004, preparations for which started in 1997, the year the International Olympic Committee (IOC) awarded the organization of the 2004 Olympic Games to Athens. The preparations for the games--mainly building up the required infrastructure - have had a longlasting economic effect. Their duration coincided with the preparation of the Greek economy to introduce the euro and the first years of its circulation. The Olympic Games were awarded when the Greek national currency was the drachmae, but when the Games actually took place, the euro was the official Greek national currency. Thus, when in macro-econometric analyses, a dummy variable is used to account for the structural change of euro; this variable simultaneously catches up to the economic effects of Olympic Games. As a coincidence, I was asked to do an economic analysis of the Olympic Games' impact simultaneously with my assignment of economic analysis of the introduction of the euro. ${ }^{2}$

The second noneconomic event was the impact of COVID-19 which led to an economic lockdown with serious economic, social and primarily health effectsnot only in Greece, but throughout the entire world. In a series of studies, I have investigated various aspects of the current pandemic by looking at what Thucydides had to say of the pandemic effect which hit Athens in 430 BCE and lasted for about 5-6 years (Papanikos 2021b). I also examined the tourism impact of COVID-19 (Papanikos 2020a).

The third event was economic. The Great Recession started in the USA in 2008 but hit Greece very hard in 2010. This has had serious economic and political repercussions which are further examined in the following sections.

There are two issues with the introduction of euro. Firstly, it is the institutional change from a national currency to a common currency. This by itself has mainly positive effects by reducing the transaction costs of doing business in the common currency of an area. As we shall see, these positive effects have been fully recognized and appreciated by the majority of people in the eurozone. Secondly, it is the actual exchange value of the common currency itself. All countries use the same nominal euro, but the real effective exchange rate for each country differs. In Papanikos (2015a), I estimated that the Greek effective exchange rate was overvalued, and a devaluation of the euro would have benefited Greece to cope with the Great Recession. Since then, the nominal value of the euro has been devaluated relative to US dollars which is usually taken as representing the foreign currency. This study does not repeat the 2015 study, but it should be clear that eurozone member-countries do not have the same real effective exchange rate which has significant effects on their international trade, and therefore GDP.

This paper is descriptive and provides an overview of how the euro affected the Greek public opinion, economy, and politics. The paper is organized into six

\footnotetext{
${ }^{2}$ The first was assigned by the Research Institute of Tourism and the second by the Government of Greece. The first produced a book publication (Papanikos 1999) and the second a report which was presented to the Ministry of Development. I have also examined the Olympic Effect in a series of articles; see Kartakoullis et al. (2003), and Papanikos (2022a, 2020e, 2004a, 2004b, 2003).
} 
sections, including this introduction. The next section discusses what Greeks think about the euro after 20 years of experience. I use the latest Eurobarometer findings. I compare the Greek feelings about the euro relative to the eurozone average. Economics is only one dimension of the euro effect. People may derive pride from using a common currency and belonging to a group of European countries. Especially for Greeks, this is felt even more sensitively because it is one of their many myths which gave the name to this continent, and now to its common currency. Thus, having the euro means more than money; it may transcend an ideal that Europeans are willing to pay the economic cost of having it.

In section three, I compare the GDP and GDP per capita performance of the Greek economy in the two decades prior, and after, the introduction of the euro. The key question in this section is whether the Greek economy did better or worse in the euro years. This is not the most appropriate comparison, but it is very difficult to simulate what would have been the economic performance of Greece without the euro and then compare it with the actual performance inside the eurozone. However, given the political animosity at the time in Greece when extremists were campaigning on the worst scenario, echoing people's many concerns because of the uncertainties of the new currency, the question of whether the Greek economy is better or worse has its own merit.

In section four, the political hostilities are examined which were instigated by the Great Recession of 2008. The section discusses the Greek politics of the euro years. The political cycle had two phases. The first lasted up to 2012 where Greek politics followed the trends of being ruled by one-party governments. The Great Recession and the fact that Greece was a member of the eurozone was a crash-test for the Greek political system. New parties emerged, and for the first time in the postwar Greek political history a coalition government was formed in 2012 which governed up to 2015, and then another coalition government ruled Greece from 2015 and 2019. On this, see Papanikos (2022b). In the last two years of the two decades of the euro, the Greek political system returned to the one-party government. This political cycle was the result of Greece being a member of the eurozone as explained in this section.

In section five the impact of COVID-19 is examined through the prism of the many papers published in ATINER's various journals. Still, the impact of COVID-19 is still in effect and no conclusion can be reached. This section emphasizes the multiple effects this pandemic has had on the economy and the society at large. In the last two years (2020-2021) more than 30 papers have been published in the various journals of ATINER; an edited book of these studies has been prepared by Boutsioli et al. (2022).

Conclusions are given in the last section and relate to the three-and-a-half issues discussed in this paper: people's opinions about the euro; the euro effect on total and per capita Greek GDP; the developments of Greek politics during the euro years; and the impact of COVID-19. 


\section{What Do the Euro Countries and Greeks Think About the Euro?}

This section looks at what Europeans have to say about the euro. The data are retrieved from the most recent Eurobarometer available (December 2021). Since the focus is on Greece, I compare the European average with the opinions of Greeks. I have selected just a few questions, but I think they are characteristic of how the euro is perceived today by Greeks, relative to the average of the 19 countries in the eurozone.

Figure 1 shows the average European's opinion about the euro. Over the last 15 years the opinion remained stable. By the end of the two decades of euro's circulation, $78 \%$ of Europeans have a positive view, while $14 \%$ think that it was a bad idea.

A common European identity can be expressed by many things, and the idea of having a common something, like a currency, is considered as an indicator of a European cohesion. The exact question asked was, "Does the euro make you personally feel more European than before or would you say that your feeling of being European has not changed?"

Figure 2 gives the percentage of all Europeans who share the common currency. It seems that over the years the idea of the common currency makes more and more people feel an affinity to Europe. In 2007, $22 \%$ of the people in the eurozone countries stated that the euro made them feel more European. In 2021, this figure was $32 \%$. Those who answered that nothing has changed decreased in number, but still dominate with $66 \%$. However, this might have an ambiguous reasoning. Those who felt as Europeans before, the euro would not have changed their attitudes towards Europe.

Figure 1. Europeans Opinion About the Euro, 2007-2021

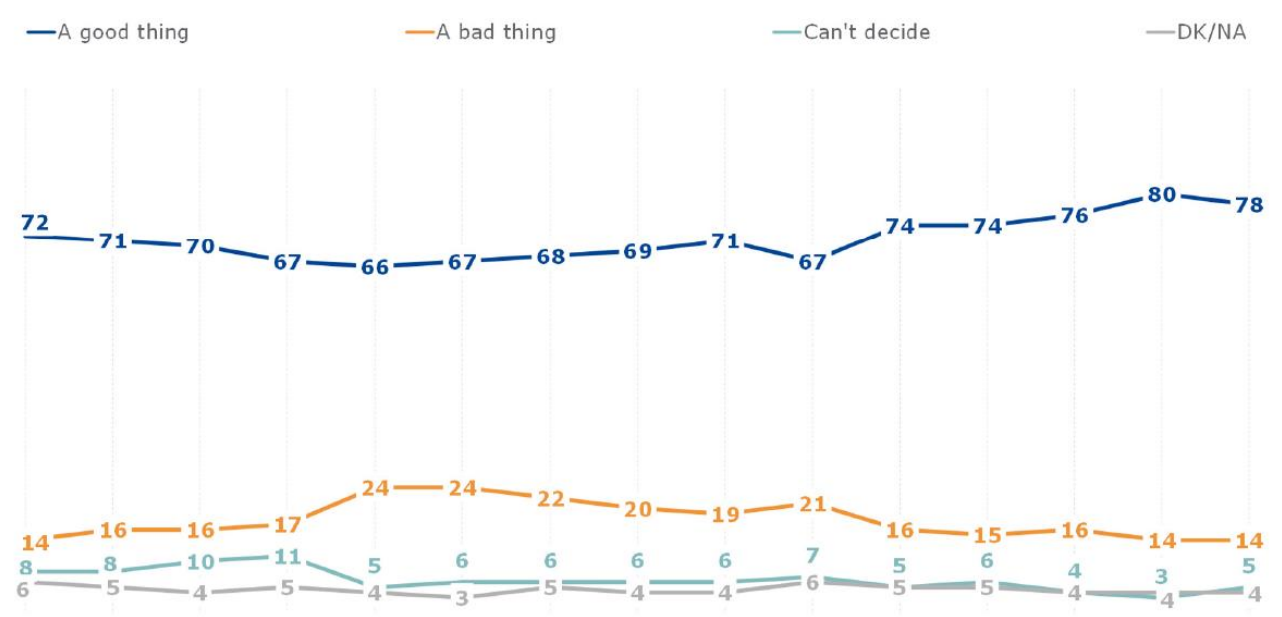


Figure 2. The European Affinity Because of the Euro, 2007-2021

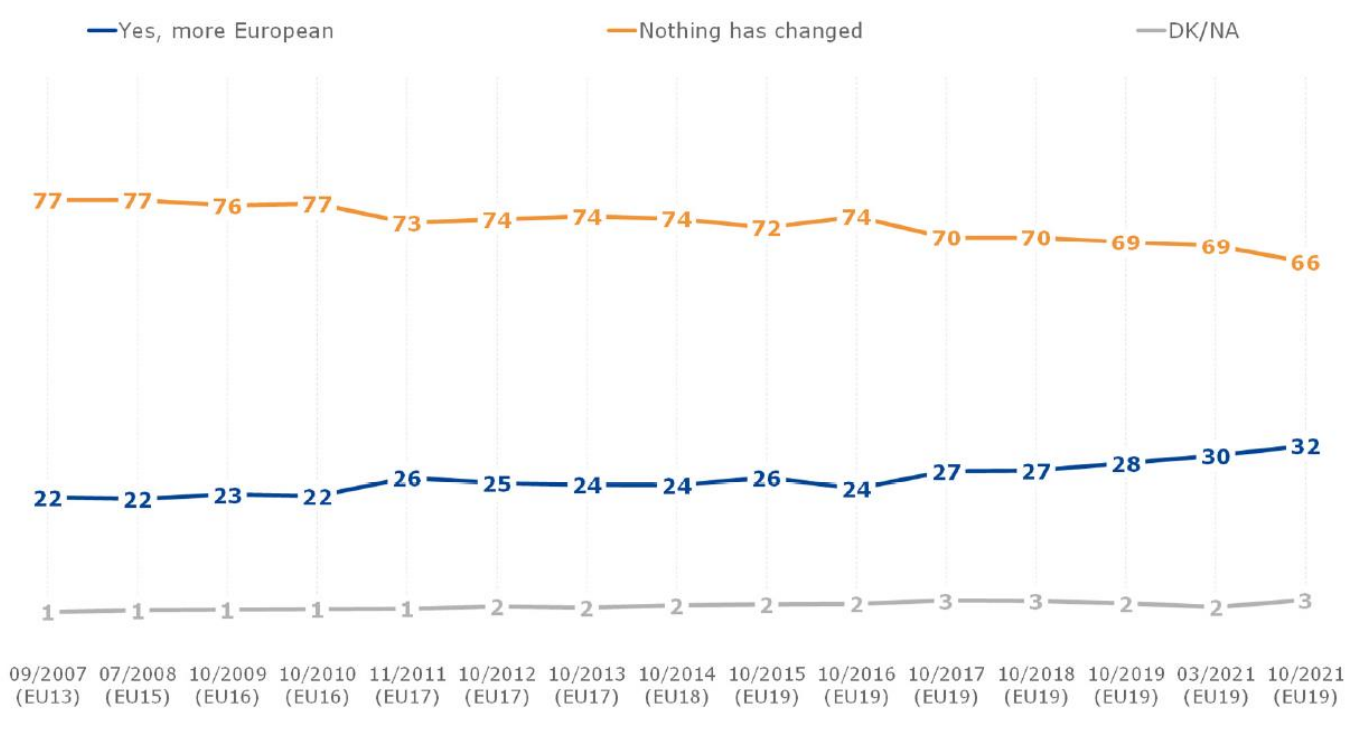

I turn now to what Greeks think about the euro and compare it with the average opinion of others in the eurozone. Table 1 compares some key questions with the Greek opinions on the euro with the average of the eurozone.

Table 1. Greece vs EU Average Opinions on the Euro, 2021

\begin{tabular}{|c|c|c|c|}
\hline No. & Question & $\begin{array}{l}\text { Eurozone } \\
\text { Average }\end{array}$ & Greece \\
\hline Q1.1 & $\begin{array}{l}\text { Generally speaking, do you think that having the Euro is a good for your } \\
\text { country? }\end{array}$ & 69 & 73 \\
\hline Q1.2 & Generally speaking, do you think that having the Euro is a good for EU? & 78 & 79 \\
\hline Q2 & $\begin{array}{l}\text { Does the Euro make you personally feel more European than before or } \\
\text { would you say that your feeling of being European has not changed? } \\
\text { More } \\
\text { Nothing Changed }\end{array}$ & $\begin{array}{l}32 \\
66\end{array}$ & $\begin{array}{l}28 \\
72\end{array}$ \\
\hline Q7.1 & Do you think that the Euro has made travelling easier and less costly? & 53 & 58 \\
\hline Q7.3 & $\begin{array}{l}\text { Do you think that the Euro has made easier to do business in different EU } \\
\text { countries? }\end{array}$ & 79 & 82 \\
\hline Q7.4 & $\begin{array}{l}\text { Do you think that the Euro has made it easier to compare prices and shop } \\
\text { in different EU countries, including online? }\end{array}$ & 82 & 85 \\
\hline Q8 & $\begin{array}{l}\text { Do you think that the degree to which economic policy, including } \\
\text { budgetary policies, is coordinated in the Euro area is appropriate? Should } \\
\text { there be more or less coordination among Euro-area governments? } \\
\text { Appropriate } \\
\text { More Coordination }\end{array}$ & $\begin{array}{l}15 \\
64 \\
\end{array}$ & $\begin{array}{c}5 \\
85\end{array}$ \\
\hline
\end{tabular}

Source: Eurobarometer, December (2021).

Greeks, on average, think that the euro is good for Greece and the eurozone relative to the eurozone's average, but there are no huge differences. On the issue of affinity, the European idea, 28\% of Greeks stated that the euro made them feel more European, relative to a $32 \%$ of the eurozone average. "Nothing changed," 
said $72 \%$ of Greeks and $66 \%$ of Europeans. However, this may be interpreted that Greeks felt more like Europeans than the rest of Europe even before the introduction of Euro.

The next three questions are economic in nature. One of the advantages of a common currency is that it reduces the transaction costs of doing business in the area. Traveling became easier, said 53\% of the Europeans, while 58\% of Greeks thought so as well. Doing business became easier, said $82 \%$ of Greeks relative to an average of $79 \%$ of all Europeans. Comparing prices became easier, stated $85 \%$ of Greeks and $82 \%$ of all Europeans.

The last question, I think, is the most important for the future of the eurozone. Most Europeans (64\%), and even many more Greeks (85\%), thought that a fiscal coordination would have been better for the eurozone. This compares with the monetary policy which is now regulated centrally by the European Central Bank. ${ }^{3}$

In general, it appears that Greeks feel, on average, that the euro was not a bad idea after all. This is very important because Greece suffered economically the most of all eurozone countries because, as I argued (Papanikos, 2015), the exchange value of the euro was detrimental for the Greek exports which included tourism revenues. However, the economic performance of the euro years did not deteriorate the economic welfare of the Greek people, as this is demonstrated by comparing the GDP and the GDP per capita in the next section.

\section{Total and Per Capita GDP}

For economists, people's opinions are considered with great skepticism. What is important is not what people say, but what they do. In economics "doing" is "producing" and "consuming". At the macroeconomic level, the GDP captures the essence of total final production generated in a given year; then divided by population is an indication of wellness of a country's economy.

Thus, did the euro produce more or less total and per capita Greek GDP? There are two ways to answer this question already mentioned in the introduction of the paper. Firstly, a more accurate measure would have been if data could be constructed of what the Greek GDP would have been without the euro. Then, these data would have been compared with the actual GDP produced in Greece as a member of the eurozone. This is not possible. Secondly, one may compare whether total and per capita GDP was higher or lower in the pre-euro period, relative to the euro period. This is shown in Figures 3 and 4.

\footnotetext{
${ }^{3}$ Of course, monetary policy relates to the value of the euro vis-à-vis other currencies (the exchange rate), the interest rate and the rate of inflation. On these issues many papers have been published in this and other journals of ATINER; see Binatli and Sohrabji (2019), Colonescu (2017, 2018), Correia (2016), Correia and Carvalho (2016), Gambarotto et al. (2019), Gentilucci (2020), Kallianiotis (2018), Klein (2021), Korus (2019), Leen (2016), Luchena Mozo (2017), Reid (2018), Siddiqui (2020), Sommeiller (2020), and Turnbull (2016).
} 
Figure 3. GDP in Billions of 2015 Euro

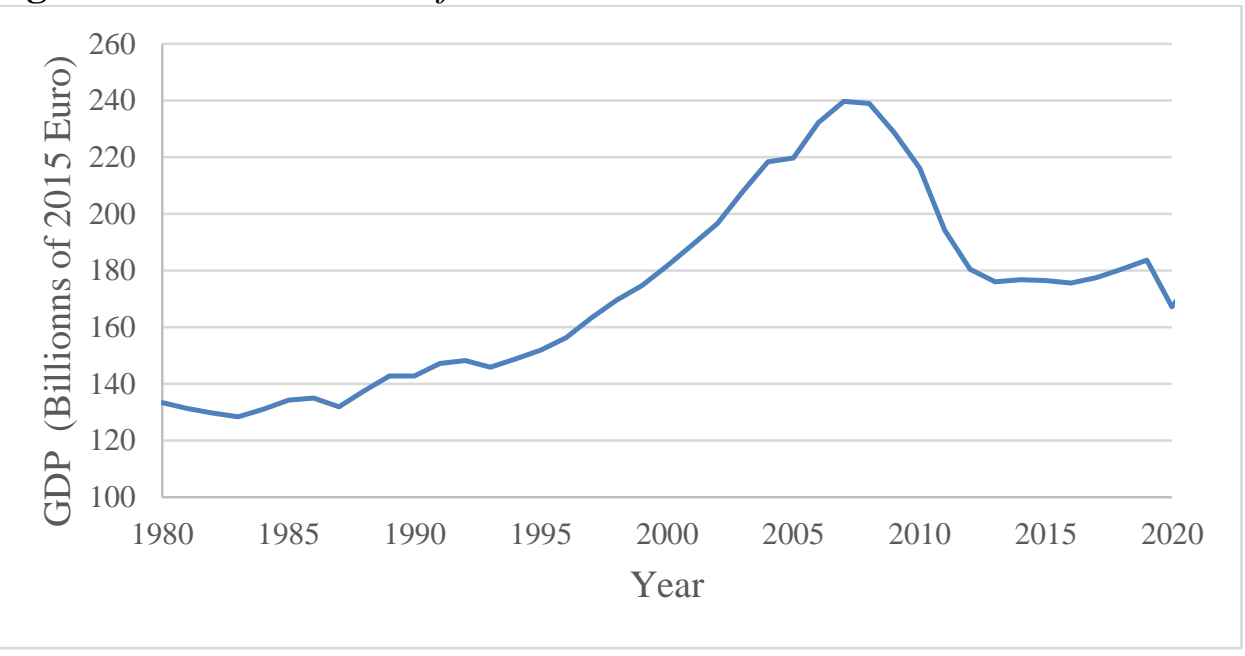

Figure 4. Per Capita GDP in Thousands of 2015 Euro

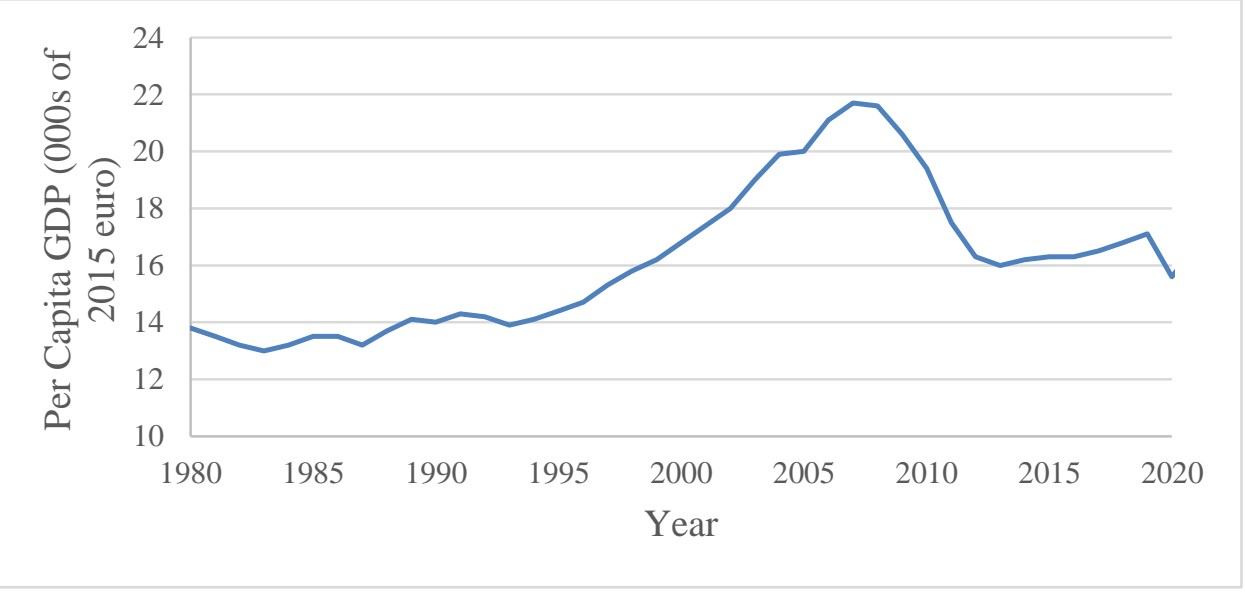

I have explained the Greek economy elsewhere in many publications, both the macroeconomic and microeconomic aspects, and I do not repeat them here. ${ }^{4}$ Instead, I make a number of points based on the two figures (Figures 3 and 4).

Firstly, the introduction of the euro was accompanied by an unprecedented increase in total and per capita GDP. Never before have the two variables reached such high levels. Even though this cannot be directly attributed to the euro itself, it does relate to the general positive international economic environment which gave rise to lower interest rates. It was this possibility of borrowing money at low rates which led the Greek Government to borrow money at unprecedented high levels

\footnotetext{
${ }^{4}$ The most important is my book (Papanikos 2014a) where I present a detailed economic analysis with an emphasis on the debt crisis of 2010. Other studies include Michelis et al. (2004), Papadopoulos and Papanikos (1997, 2002, 2005), Papanikos (2014a-c, 2015a-j). In addition, the Greek economy, and especially its tourist sector, is affected by the political and military developments in the Eastern Mediterranean. On the issue of military and its effect on international trade and economic growth see Papanikos (2015k), and on the issue of energy see Papanikos (2017). The thorny issue of Greek-Turkish relations is examined in Papanikos (2020c, 2020d, and 2021e).
} 
which led to the Greek debt crisis of 2010 as I demonstrated with all the details and data in Papanikos (2014a).

Secondly, after 2008 the total and per capita GDP dramatically decreased at unprecedented rates for peace years. Never before had the rates of growth of the two variables reached so low. This was the effect of the Great Recession and the debt crisis previously mentioned.

Thirdly, despite these huge variations in total and per capita GDP, these two variables remained higher than any value of the pre-euro period with the exception of the two years of 2020 and 2021 when the lockdown due to COVID-19 hit all the eurozone economies harshly.

\section{The Greek Political Debate in the Euro Years}

This section builds on my previous writings and my personal experience as a policymaker. ${ }^{5}$ From 1997 until 2011, I served as a General Secretary of the Greek Economic and Social Council, which provided me with firsthand experience with the politics of the debate. For many people, the euro meant an increase in their economic welfare. They thought that the euro would bring higher wages, lower unemployment rates, inflation rates and borrowing rates.

Starting in 2002, the political debate of whether Greece was ready to switch between currencies was over. Issues such as the change of menu prices and cashiers disappeared from the mass media in the first month of 2002. There were not the huge transaction costs many were expecting. Nobody even noticed that real wages were increasing at a higher rate than productivity. The gap was filled with foreign borrowing which no political party condemned, with the exception of a handful of politicians. In elections after elections, from the 1980s onwards (Table 2 ), the issue of Europe was at the top of the political agenda.

Table 2. Elections Years, 1983-2021

\begin{tabular}{|c|c|c|}
\hline Year & Party Coming First Relative to Previous Elections & Type of Government \\
\hline 1985 & Same & One party \\
\hline 1989 & Change & Interim \\
\hline 1990 & Same & Interim \\
\hline 1990 & Same & One party \\
\hline 1993 & Change & One party \\
\hline 1996 & Same & One party \\
\hline 2000 & Same & One party \\
\hline 2004 & Change & One party \\
\hline 2007 & Same & One party \\
\hline 2009 & Change & One party \\
\hline 2012 & Change & Interim \\
\hline 2012 & Same & Coalition \\
\hline 2015 & Same & Coalition \\
\hline 2015 & Same & Coalition \\
\hline 2019 & Change & One party \\
\hline
\end{tabular}

\footnotetext{
${ }^{5}$ See among many others Papanikos (2014a, 2019, 2021d, 2022b).
} 
The most important elections which took place in the euro years was in 2012 for two reasons. Firstly, for the first time since 1974 the two opposition parties formed a coalition government to deal with the real threat of Greece being pushed out of the eurozone. Never before was Greece at the brink of getting out of the eurozone and maybe even from the European Union. This collaboration gave rise to the growth of many small parties, which in the general elections of 2015, led to another party which was far away from what many voters would have thought a few years back. A left party collaborated with an extreme right party, even though there was the alternative option for the left to collaborate with a center or centerleft party to form a government. The rest of this section is devoted to the two political events.

\section{The 2012 Double Elections}

The Greek general elections of the $6^{\text {th }}$ of May 2012 did not result in the formation of a coalition government. According to the Greek Constitution, new elections were called for on the $17^{\text {th }}$ of June 2012 .

The five-and-a-half weeks between the two elections gave the opportunity to all Greek parties to reconsider their positions and form pre-election coalitions which are based on the three main issues of the May and the June elections. These issues are (Table 3):

1. The classical ideological division between right and left, or center-right and center-left.

2. The split between those who want the euro and those who prefer a return to a national currency.

3. The position between the necessity of the austerity measures imposed by the troika and those who wanted a unilateral abolishment of them.

Table 3. Typology of Issues

\begin{tabular}{|l|c|c|}
\hline Issue & \multicolumn{2}{|c|}{ Options } \\
\hline Ideology & Center-Right & Center-Left \\
\hline Eurozone-European Union & Pull out & Stay in \\
\hline Austerity Measures & Necessary & Not Necessary \\
\hline
\end{tabular}

The new elections made it even clearer the political parties' positions on the last two issues of the euro and the austerity measures. It should be mentioned that those political parties which considered the austerity measures necessary also agreed that the austerity program needed to be reconsidered towards (a) extending the implementation period and (b) supplementing the austerity program with measures to promote output growth and employment. They considered the new political developments in Europe, primarily the election of Francois Holland in France, as more favorable towards a renegotiation of the austerity measures with the troika.

The results of the election of the 17 of June 2012 and of 6 of May 2012 were analyzed along three lines: ideology, political parties' stance on the eurozone, and 
their attitude towards the austerity program. In sum, the main points are the following:

1. Although June 2012 elections were considered very important, $37.53 \%$ of the eligible Greek voters decided not to vote (Table 4). This was higher than the May 2012 percentage of $34.9 \%$, and even higher than the $29.05 \%$ of the 2009 elections. This is not interpreted as political apathy, but as a deliberate protest against the political system. Some voters might have abstained because they did not want to vote against their traditionally preferred political party.

2. Contrary to the May 2012 election results, in the June 2012 elections only $5.98 \%$ of the electorate was not represented in the parliament because they did not meet the required statutory minimum rate of $3 \%$ of the votes. In May $2012,19 \%$ of the Greek voters chose a party that is not represented in the Parliament. The 2009 rate was only 5\%.

3. On the ideology issue, the percentages remained the same with a very small increase to the left of $0.54 \%$ (Table 5).

4. On the eurozone membership issue (Table 6), in 2012 the Greek electorate had the option for the first time to vote for parties which openly declared their devotion or hostility to the euro experiment. In May 2012, 81.92\% of Greeks voted for parties which see Greece's future inside the eurozone. In June 2012 this percentage increased to $88.04 \%$. This is very high and similar to the Eurobarometer's measure in the end of 2021.

5. On the austerity issue (Table 7), in June 2012, 52.96\% of Greeks voted for parties which claim that austerity measures are painful but necessary. In May 2012 the rate was $51.65 \%$.

Table 4. Greek Elections of June 2012 and May 2012

\begin{tabular}{|c|c|c|c|c|}
\hline & $\begin{array}{c}\text { People entitled to } \\
\text { vote } \\
(1)\end{array}$ & $\begin{array}{c}\text { Number of People } \\
\text { Voted } \\
(2)\end{array}$ & $\begin{array}{c}\text { Percent of } \\
\text { People Voted } \\
(3)\end{array}$ & $\begin{array}{c}\text { Percent of Voters } \\
\text { Abstained } \\
(4)\end{array}$ \\
\hline June 2012 & $9,949,300$ & $6,215,029$ & $62.47 \%$ & $37.53 \%$ \\
\hline May 2012 & $9,949,401$ & $6,477,060$ & $65.10 \%$ & $34.9 \%$ \\
\hline
\end{tabular}

Table 5. Right and Left

\begin{tabular}{|l|c|c|c|}
\hline \multicolumn{1}{|r|}{ Election Year } & $\begin{array}{c}\text { June 2012 } \\
\text { Ideology }\end{array}$ & $\begin{array}{c}\text { May 2012 } \\
\%\end{array}$ & $\begin{array}{c}\text { June 2012/May } \\
2012 \\
\% \text { Difference }\end{array}$ \\
\hline Right to Center & $48.26 \%$ & $49.00 \%$ & $-0.74 \%$ \\
\hline Left to Center & $51.47 \%$ & $50.93 \%$ & $+0.54 \%$ \\
\hline
\end{tabular}

Table 6. In and Out of the Eurozone

\begin{tabular}{|l|c|c|c|}
\hline \multicolumn{1}{|r|}{ Election Year } & $\begin{array}{c}\text { June 2012 } \\
\text { Eurozone }\end{array}$ & $\begin{array}{c}\text { May 2012 } \\
\%\end{array}$ & $\begin{array}{c}\text { June 2012/May } \\
2012 \\
\% \text { Difference }\end{array}$ \\
\hline In & $88.04 \%$ & $81.92 \%$ & $+6.12 \%$ \\
\hline Out & $11.96 \%$ & $18.08 \%$ & $-6.12 \%$ \\
\hline
\end{tabular}


Table 7. Austerity Measures

\begin{tabular}{|l|c|c|c|}
\hline \multicolumn{1}{|c|}{ Election Year } & $\begin{array}{c}\text { June 2012 } \\
\%\end{array}$ & $\begin{array}{c}\text { May 2012 } \\
\%\end{array}$ & $\begin{array}{c}\text { June 2012/May } \\
2012 \\
\% \text { Difference }\end{array}$ \\
\hline $\begin{array}{l}\text { Austerity Measures } \\
\text { Eurozone }\end{array}$ & $52.96 \%$ & $51.65 \%$ & $1.31 \%$ \\
\hline Not necessary & $47.04 \%$ & $48.35 \%$ & $-1.31 \%$ \\
\hline Difference & $5.92 \%$ & $3.30 \%$ & $2.62 \%$ \\
\hline
\end{tabular}

The Double Elections of 2015 and the Referendum in Between

The coalition government ruled until early 2015, when, on the issue of choosing the next President of the Hellenic Republic, the parliament was unable to elect a president. According to the constitution, a new election was called. As all had expected, a left party won the elections on the $25^{\text {th }}$ January 2015.

Analyzing the election results (Papanikos 2015h), I had predicted that new general elections were coming. These new elections were called early in the fall of the same year. In between, there was a referendum. On this, in my book (Papanikos 2014a, p. 147) I had predicted that the left power, when it would come to power, would (a) call for a referendum, (b) the question would be vague so it can be interpreted as either a no to euro or a no to the memorandums in general, or a no to a specific memorandum which allegedly was on the table, but the eurozone countries took it off once the referendum was called, and (c) Greeks would vote no because when people are directly or indirectly asked if they want to pay taxes they will say no. This is the reason tax and budget issues cannot be determined in a referendum as is clearly stated in the Greek Constitution.

\section{The COVID-19 Impact}

In 2019 new elections were held and a new one-party government of the traditional Greek right was formed. However, the new government was faced with the challenge of COVID-19, of which the effects are still on and nobody can predict how long it will last. On this issue, I have written extensively. In Papanikos (2021b), I looked at how a pandemic influenced the economic and social life in ancient Athens as described by Thucydides. The effect of the pandemic at the European Union level was examined in Papanikos (2020b). I also examined the devastating effect on Greek tourism in Papanikos (2020a). Finally, the EU's recovery plan was analyzed in Papanikos (2021c).

COVID-19 has many impacts. In a series of papers published in the various journals of ATINER, the themes included: Health Issues (Menekli et al. 2021, Papanikos 2021a, Parodi et al. 2021, Shah et al. forthcoming), Mass Media and Communication Issues (Crescentini and Padricelli forthcoming, De Falco et al. 2021, Fitzpatrick forthcoming, Mengu et al. 2021, Osisanwo 2022); Social Aspects (Bäckman 2021, Jurić 2022, Lust forthcoming, Okaka and Omondi forthcoming, Papanikos 2020b, Polo Martín 2022); Business and Economics Issues (Adejare et al. forthcoming, Papanikos 2021c, Reid forthcoming, Struwig and Watson 
forthcoming, Uwah et al. forthcoming); Tourism Issues (Gukiina and Lamunu 2021, Jones forthcoming, Jones and Comfort 2020, Papanikos 2020a); Education Issues (Güvercin et al. forthcoming, Ismaili and Ibrahimi 2021, Papanikos 2021b); Law Issues (Iancu 2021, Patraus and Ofrim 2021).

The above literature shows that the impact of COVID-19 is a very serious one and no one can predict when it will end.

\section{Conclusions}

This paper investigated the opinions of Europeans and Greeks about the euro twenty years after its circulation. About four-fifths of people in the eurozone think that the euro is good for their country and Europe at large.

Despite the dismal picture painted and the uncertainty surrounding the introduction of the euro, the Greek economy did better in the two decades of the euro, relative to the two decades preceding the introduction of the euro.

The politics during the same period were stable up to the Great Recession of 2008. The Greek economy was hit hard; the hardest in Europe. The need to implement harsh austerity measures undermined the trust in Europe and in the euro. This shattered the political developments in Greece, leading to double elections within one year (in both 2012 and 2015). At the end of this period (20192021), these political episodes have subsided and again Greece is governed by a strong one-party government. However, COVID-19 has hit the whole world but it seems that the European Union has decided to cope with this new challenge following a different approach. Since the impact is still active, only the future will show whether these measures were effective. Future studies will definitely examine this issue.

\section{References}

Adejare BO, Olaore GO, Udofia EE, Adenigba OA (forthcoming) COVID-19 pandemic and business survival as mediation on the performance of firms in the FMCG-sector. Athens Journal of Business \& Economics. Available at: https://www.athensjournals. gr/business/2021-4138-AJBE-Adejare-07.pdf.

Bäckman G (2021) The outbreak of coronavirus (COVID-19) plagues the world. Athens Journal of Social Sciences 8(3): 181-190.

Binatli AO, Sohrabji N (2019) Monetary policy transmission in the Eurozone. Athens Journal of Business \& Economics 5(1): 79-92.

Boutsioli Z, Bigelow V, Gkounta O (2022) Essays on COVID-19. Athens: Athens Institute for Education and Research (ATINER).

Colonescu C (2017) Macroeconomic effects of the European Monetary Union: a counterfactual analysis. Athens Journal of Business \& Economics 3(2): 171-186.

Colonescu C (2018) The effects of Donald Trump's tweets on US financial and foreign exchange markets. Athens Journal of Business \& Economics 4(4): 375-388.

Correia L (2016) The European crisis: repercussions on the Portuguese economy. Athens Journal of Mediterranean Studies 2(2): 129-144. 
Correia L, Carvalho D (2016) Cyclical dynamics of unemployment: Portugal versus the euro area. Athens Journal of Business \& Economics 2(2): 149-166.

Crescentini N, Padricelli GM (forthcoming) The relevance of scientific dissemination during the vaccine campaign: the Italian virologist communication on social media. Athens Journal of Mass Media and Communications. Available at: https://www. athensjournals.gr/media/2021-4354-AJMMC-SOC-Crescentini-07.pdf.

De Falco CC, Punziano G, Trezza D (2021) A mixed content analysis design in the study of the Italian perception of COVID-19 on Twitter. Athens Journal of Social Sciences 8(3): 191-210.

Fitzpatrick N (forthcoming) No news is not good news: the implications of news fatigue and news avoidance in a pandemic world. Athens Journal of Mass Media and Communications. Available at: https://www.athensjournals.gr/media/2021-4336AJMMC-SOS-Fitzpatrick-05.pdf.

Gambarotto F, Rangone M, Solari S (2019) Financialization and deindustrialization in the Southern European periphery. Athens Journal of Mediterranean Studies 5(3): 151172.

Gentilucci CE (2020) The Mediterranean model in European economic thought. Athens Journal of Mediterranean Studies 6(3): 179-198.

Gukiina J, Lamunu E (2021) The near abasement of Uganda hotels' staff altruistic behaviour by COVID-19 pandemic: a relief model. Athens Journal of Tourism 8(4): 269-290.

Güvercin D, Kesici AE, Akbaşlı S (forthcoming) Distance education experiences of teacher-parents during the COVID-19. Athens Journal of Education. Available at: https://www.athensjournals.gr/education/2021-4145-AJE-Kesici-05.pdf.

Iancu L-O (2021) Insolvency of the natural person and COVID-19 in Romania. Athens Journal of Law 7(4): 563-574.

Ismaili J, Ibrahimi EHO (2021) The D-learning alternative during COVID-19 crisis: a preliminary evaluation based on Kirkpatrick's model. Athens Journal of Technology and Engineering 8(2): 181-198.

Jones P (forthcoming) A review of the UK's tourism recovery plans post COVID-19. Athens Journal of Tourism. Available at: https://www.athensjournals.gr/tourism/20 21-4470-AJT-Jones-03.pdf.

Jones P, Comfort D (2020) The COVID-19 crisis, tourism and sustainable development. Athens Journal of Tourism 7(2): 75-86.

Jurić T (2022) Google trends as a method to predict new COVID-19 cases and sociopsychological consequences of the pandemic. Athens Journal of Mediterranean Studies 8(1): 67-92.

Kallianiotis IN (2018) How efficient is the foreign exchange market? Athens Journal of Business \& Economics 4(3): 293-326.

Kartakoullis N, Papanikos G, Karlis G (2003) City and sport marketing strategy: the case of Athens 2004. The Sport Journal 6(2): 1-6.

Klein C (2021) The never-ending quest for the European fiscal policy's objectives: stability vs. convergence or stability and convergence? Athens Journal of Business \& Economics 7(1): 41-66.

Korus A (2019) Spillover effects from the ECB's unconventional monetary policies: the case of Denmark, Norway and Sweden. Athens Journal of Business \& Economics 5(1): 53-78.

Leen AR (2016) The multiannual financial framework of the European Union: a political power game. Athens Journal of Social Sciences 3(1): 7-18.

Luchena Mozo GM (2017) Progress in the revision of inheritance and gift tax under the European Union law: judgement of the EU court of justice (seventh chamber), 26 
May 2016, commission v Greece (C-244/15, CLI:EU:C:2016:359). Athens Journal of Law 3(2): 121-140.

Lust J (forthcoming) The structural conditions for the expansion of COVID-19 in Peru. Athens Journal of Social Sciences. Available at: https://www.athensjournals.gr/social/ 2021-4173-AJSS-SOC-Lust-05.pdf.

Menekli T, Doğan R, Yıldız E (2021) Relationship between stress perceived and gastrointestinal symptoms in intensive care nurses during COVID-19 pandemic: a cross-sectional study. Athens Journal of Health and Medical Sciences 8(4): 217-230.

Mengu S, Mengu M, Gunay K (2021) Value-based communication during COVID-19 pandemic: a study on the twitter messages of Turkish Ministry of Health. Athens Journal of Mass Media and Communications 7(1): 23-44.

Michelis L, Papadopoulos AP, Papanikos GT (2004) Regional convergence in Greece in the 1980s: an econometric investigation. Applied Economics 36(8): 881-888.

Okaka FO, Omondi P (forthcoming) Knowledge, attitude, and practices (KAP) towards COVID-19 among older people living in informal settlements in Nairobi City, Kenya. Athens Journal of Social Sciences. Available at: https://www.athensjournals. gr/social/2021-4430-AJSS-SOS-Okaka-05.pdf.

Osisanwo A (2022) "This virus is a common threat to all humans": discourse representation of COVID-19 in selected newspaper editorials. Athens Journal of Mass Media and Communications 8(1): 59-78.

Papadopoulos AP, Papanikos GT (1997) Single European currency: implications for Greek Industry. Part of the Project The Future of Greek Industry. Ref. No.: A/EПВ12054/403/Ф.6.1.3. Athens: Greek Government (Ministry of Development).

Papadopoulos AP, Papanikos GT (2002) Exchange rate regimes and the linkage between money and output in Greece. Journal of Policy Modelling 24(2): 103-117.

Papadopoulos AP, Papanikos GT (2005) The determinants of vinegrowers employment and policy implications: the case of a Greek island. Agricultural Economics 32(1): $61-72$.

Papanikos GT (1999) Tourism impact of the 2004 Olympic Games (in Greek). Athens: Tourism Research Institute, https://bit.ly/3qtun4b.

Papanikos GT (2003) The economics of professional sports and Olympic Games. Athens: Athens Institute for Education and Research (ATINER), https://bit.ly/3qFUgxC.

Papanikos GT (2004a) The economics and management of mega athletic events: Olympic Games, professional sports, and other essays. Athens: Athens Institute for Education and Research (ATINER), https://bit.ly/3sWOQBm.

Papanikos GT (2004b) The determinants of employment creation in small regional firms. International Regional Science Review 27(2): 187-204, https://bit.ly/3erEL6P.

Papanikos GT (2014a) The economic crisis of Greece: a class analysis in support of memorandums (in Greek). Athens: Athens Institute for Education and Research (ATINER), https://bit.ly/3zau3LK.

Papanikos GT (2014b) Greek trade unions, the euro and the current crisis. The Singapore Economic Review 59(4): S1-S2, https://bit.ly/3zqiBLO.

Papanikos GT (2014c) The Greek sovereign debt: are there really any options? Romanian Journal of Fiscal Policy 5(2): 1-25, https://bit.ly/3HeEL6z.

Papanikos GT (2015a) The real exchange rate of euro and Greek economic growth. Journal of Economic Asymmetries 12(Nov): 100-109, https://bit.ly/3qq4m5H.

Papanikos GT (2015b) Taxing wealth and only wealth in an advanced economy with an oversized informal economy and vast tax evasion: the case of Greece. Vierteljahrshefte zur Wirtschaftsforschung, DIW Berlin 84(3): 85-106, https://bit.ly/3Hc8BbS. 
Papanikos GT (2015c, May 27) A Grexit would not be a catastrophe for all. LSE European Politics and Policy (EUROPP) Blog.

Papanikos GT (2015d, April 13) The Greek economic crisis: facts and myths. Available at: http://www.atiner.gr/gtp/The Nature of Greek Economic Crisis.pdf, https://bit.ly/3JkfFVQ.

Papanikos GT (2015e, March 4) The long and winding road to reform Greece's economy. The Conversation.

Papanikos GT (2015f, February 4) Greece's new debt deal may appease creditors but it won't help the economy. The Conversation.

Papanikos GT (2015g, January 26) The "Works and Days" of Syriza's first week in power. Available at: http://www.atiner.gr/gtp/The Works and Days of Syriza's first week in power.pdf, https://bit.ly/3qMNxSH.

Papanikos GT (2015h, January 26) With Greece backing euro but Syriza in government, another election may beckon. The Conversation and New Statesman.

Papanikos GT (2015i, January 22) ECB decision should be good news for Greece, but Syriza will get in the way. The Conversation.

Papanikos GT (2015j, January 6) Hard evidence: can Germany throw Greece a lifeline and save the euro? The Conversation.

Papanikos GT (2015k) Spending, international trade and economic growth in the Mediterranean basin. Athens Journal of Mediterranean Studies 1(2): 187-194, https://bit.ly/3z2lUc6.

Papanikos GT (2017) Energy security, the European Energy Union and the Mediterranean countries. Athens Journal of Mediterranean Studies 3(4): 341-354, https://bit.ly/3H6pgO6.

Papanikos GT (2019) Andreas G. Papandreou: economist and prime minister (in Greek). Athens, Greece: Athens Institute for Education and Research (ATINER), https://bit.ly/3FMYryl.

Papanikos GT (2020a) The impact of the COVID-19 pandemic on Greek tourism. Athens Journal of Tourism 7(2): 87-100, https://bit.ly/3mDAfqi.

Papanikos GT (2020b) The demographics of COVID-19 in the European Union. Athens Journal of Social Sciences 7(4): 279-290.

Papanikos GT (2020c) Could this have been written by the great president of Turkey? Libya versus Cyprus. Mimeo. Available at: https://bit.ly/3qqirAd.

Papanikos GT (2020d) Turkey is on the right side of history on Hagia Sophia. Mimeo. Available at: https://bit.ly/3qs0BNl.

Papanikos GT (2020e) The participation legacy at Olympic Games. Athens Journal of Sports 7(4): 251-262, https://bit.ly/3mAr8a1.

Papanikos GT (2021a) Deaths due to COVID-19, lockdowns, vaccinations and weather temperatures: the case of Greece. Athens Journal of Health and Medical Sciences 8(3): 201-216, https://bit.ly/3ESOyOd.

Papanikos GT (2021b) Thucydides and the synchronous pandemic. Athens Journal of History 7(1): 71-94, https://bit.ly/3Jpvk6q.

Papanikos GT (2021c) The European Union's recovery plan: a critical evaluation. Athens Journal of Mediterranean Studies 7(2): 85-102, https://bit.ly/32CMVH5.

Papanikos GT (2021d, October 30) Estimates of electing the leader of PASOK in the forthcoming elections of 5 and/or 12 December 2021. Working Paper (in Greek). Available at: https://bit.ly/3GHJ6iv.

Papanikos GT (2021e) Turkey at the dawn of the 2020s: old challenges and new prospects. Athens Journal of Mediterranean Studies 7(4): 253-266, https://bit.ly/315pfL0. 
Papanikos GT (2022a) An ex-post analysis of the 2004 Olympic effect Athens Journal of Sports (forthcoming), https://bit.ly/3JiXHDb.

Papanikos GT (2022b) The use of primaries by political parties: the case of PASOK. Athens Journal of Social Sciences. 9(2): 201-222, https://bit.ly/3sCbfnb.

Parodi P, Maraglino F, Caraglia A (2021) The impact of COVID-19 epidemic on immunization activities in Italy. Athens Journal of Health and Medical Sciences 8(1): 53-66.

Patraus ME, Ofrim IM (2021) Contractual unpredictabiliy in the context of COVID-19 pandemic. Athens Journal of Law 7(4): 485-506.

Polo Martín B (2022) COVID-19: cartography as a witness of change of Spanish urban models along history due to sanitary crisis. Athens Journal of Mediterranean Studies 8(1): $29-48$.

Reid JL (2018) Has the Brexit vote affected the United Kingdom's largest trading partners? Athens Journal of Social Sciences 5(3): 291-312.

Reid JL (forthcoming) The economic effect of the COVID-19 lockdown in the United States: was the cure worse than the disease? Athens Journal of Health and Medical Sciences. Available at: https://www.athensjournals.gr/health/2021-4261-AJHMSPOL-Reid-05.pdf.

Shah FA, Ali MA, Naeemullah, Bilal M (forthcoming) A study of paediatric supracondylar fractures of the humerus presented during the COVID-19 pandemic. Athens Journal of Health and Medical Sciences. Available at: https://www.athensjour nals.gr/health/2020-3855-AJHMS-Shah-09.pdf.

Siddiqui K (2020) The U.S. dollar and the world economy: a critical review. Athens Journal of Business \& Economics 6(1): 21-44.

Sommeiller E (2020) The working poor facing the great recession in Southern Europe. Athens Journal of Business \& Economics 6(4): 303-330.

Struwig M, Watson S (forthcoming) Working capital management and systems disruption during the COVID-19 pandemic: evidence from South Africa. Athens Journal of Business \& Economics. Available at: https://www.athensjournals.gr/business/20214266-AJBE-MGT-Struwig-05.pdf.

Turnbull S (2016) Terminating currency options for distressed economies. Athens Journal of Social Sciences 3(3): 195-214.

Uwah UE, Udoayang JO, Uklala PA (forthcoming) Post COVID-19 and the acceptance of financial inclusion as a new normal in financial transactions: implications for Nigerian accountants and other financial service providers. Athens Journal of Business \& Economics. Available at: https://www.athensjournals.gr/business/20203821-AJBE-ACC-Uwah-05.pdf. 